DOI: 10.46340/ephd.2021.7.1.11

Hanna Kostenko

ORCID ID: https://orcid.org/0000-0002-2731-5251

V. N. Karazin Kharkiv National University, Ukraine

\title{
DECOLONIZATION AS INITIATION: THE HERO'S PATH TO FREEDOM THROUGH \\ THE DESERT OF THE EMPIRE IN THREE GENERATIONAL NOVELS BY SERHIY ZHADAN
}

\author{
Ганна Костенко \\ Харківський національний університет імені В.Н. Каразіна, Україна

\section{ДЕКОЛОНІЗАЦІЯ ЯК ІНІЩАЦІЯ: \\ ШЛЯХ ГЕРОЯ ДО СВОБОДИ КРІЗЬ ПУСТЕЛЮ \\ ІМПЕРІЇ В ТРЬОХ ПОКОЛІННИЦЬКИХ РОМАНАХ СЕРГІЯ ЖАДАНА}

The article analyzes the elements of replication of empire power and attempts to get rid of imperial power in modern Ukrainian culture on the basis of three novels by Serhiy Zhadan "Depeche Mode" (2004), "Voroshilovgrad" (2010), "Boarding School" (2017). Among the main means of postcolonial resistance in the texts of the novels there are the personal responsibility of each member of the postcolonial national community, a clear axiological hierarchy in society, which highly exalts the value of statehood and national identity for the former colony. The example of the translation of one of S. Zhadan's novels emphasizes the specific nature of relations in the colony-empire paradigm. This nature excludes the possibility of any fruitful "dialogue of cultures", but reveals the consumer intention of the imperial community. Also, the nature of these relations discloses consumer intention of the imperial community, which even under formal political independence perceives (post) colonial community not as an equal cultural, political, economic state, but always a resource for the development of the empire itself. It turns out that the renunciation of personal responsibility, chaos and blurred meanings in the minds of the postcolonial community creates a certain ideological and value emptiness. The last one is dangerous destructive social phenomena, namely the preparation of fertile ground for military aggression by the former empire.

The example of Serhiy Zhadan's three novels shows that an appeal to a common historical past for the empire and the colony, a specific pro-imperial policy of memory, together with the encouragement of paternalism and infantilism of the (post) colonial community are the effective means of hybrid warfare against the former colony. The article illustrates the growth of crisis phenomena in eastern Ukraine, insofar as it is depicted in the novel reality of S. Zhadan, and presents the way out of the crisis of the main character of the last novel-reinventing his own Ukrainian identity, saving himself through saving and protecting others, responsibility for own life and own land.

The author concludes, on the one hand, about the renewal of imperial power discourse in the mind of the reader by the artistic reality of novels, on the other hand, about the outline of the effective means of postcolonial liberation (those used by the protagonists of S. Zhadan's works), which can be effective not only in the literature, but also in the real life

Keywords: postcolonial narrative, philosophy of culture, philosophical anthropology, discourses of power, postcolonialism, infantilism, fatherhood, empire.

Постановка проблеми. Стан постколоніальності сучасної української культури проявляється, серед іншого, в текстах сучасної національної літератури, якими є розглянуті нижче романи, i вимагає нових комплексних філософсько-антропологічних досліджень, в тому числі і з емансипаційною, 
деколоніальною соціально-терапевтичною метою, оскільки є певною фіксацією стану національної культури після травми перебування під тоталітарно-імперським пануванням. Окремо актуалізується наше дослідження через наявність постколоніальних викривлень національної самоідентифікації в культурному полі на фоні імперського реваншизму, що продовжує свій вплив через механізми культурної експансії та гібридної війни проти незалежності колишньої колонії.

Ступінь дослідження, аналіз останніх публікацій. Колоніальна система до часів Другої світової війни була органічною частиною всесвітнього економічного і політичного простору і не підлягала суттєвій, зокрема ціннісно-етичній, ревізії - питання було лише в ступені лояльності до підлеглих, перевага умовної білої людини стосовно тубільної спільноти не обговорювалася. У другій половині $\mathrm{XX}$ століття, завдяки отриманню рядом колоній фактичної державної незалежності, а також ряду теоретичних робіт, зокрема таких добре відомих дослідників пост- та антиколоніальності, як Едвард Саїд, Франц Фанон, Гомі Бгабга та багатьох інших, постає питання не тільки і не стільки державної, а і політичної, економічної та культурної незалежності колоній, реабілітації та емансипації представників колонізованої спільноти. Економічні фактори в цьому контексті постають в своєму органічному зв'язку з культурницькими - колонізації починаються зброєю та грошима, однак підтримуються - особливо в сучасному гібридному світі - саме засобами культури. Це є лейтмотивом ключових теоретичних антиколоніальних досліджень: «Культурний процес слід розглядати як неодмінний, формуючий і зміцнюючий контрапункт до економічної й політичної машинерії в матеріальному центрі імперіалізму» ${ }^{1}$.

Внаслідок розвитку постколоніальних студій також розширюється поле застосування парадигмального аналізу антиколоніального дискурсу, приходить розуміння, що драматургія стосунків колонія-імперія виходить за межі стандартного розуміння часів Великих географічних відкриттів, що колонізований та колонізатор можуть не відрізнятися за расою та кольором шкіри, між їх звичними ареалами перебування можуть не лежати океани, їх економічно та політично-формаційний лад може не відрізнятися суттєво, однак завжди це буде визиск, диктат та нееквівалентний обмін, який буде нагадувати не «діалог культур» (політкоректний термін, за яким лукаво приховуються сучасні неоколонізатори), а поглинання і перетворення імперським центром тих явищ національної культури (економічних та виробничих потужностей, природних багатств, корисних копалин, тощо), які сама імперія номінує периферійними, легітимізуючи на рівні лексики їх стан ресурсу для себе.

Центральні роботи, присвячені дослідженню українського постколоніального дискурсу, належать О. Забужко ${ }^{2}$, Т. Гундоровій ${ }^{3}$, М. Рябчуку, М. Павлишину, Г. Грабовичу, П. Іванішину. Велику увагу проблемам колоніалізму присвятили філософи В. Кебуладзе, І. Лосєв, О. Титар ${ }^{4}$.

Мета дослідження: проаналізувати елементи реплікації влади імперії та постколоніального звільнення в сучасній українській культурі на матеріалі трьох романів Сергія Жадана «Депеш Мод» (2004), «Ворошиловград» (2010), «Інтернат» (2017).

Виклад основного матеріалу та результатів дослідження.

Споживання імперією ресурсів колонії може відбуватися багатьма шляхами, один з них культурна апропріація. Про це явище заговорили ${ }^{5}$ останнім часом у зв'язку 3 активним користуванням культурою США культури корінного населення американського континенту, а саме підкорених та фактично знищених європейськими переселенцями індіанців, а також культури афроамериканців. Нескладно згадати подібні випадки в російській практиці культурної апропріації це і скандал з атрибуцією борща як української страви, і сумнівні жарти над українським малим гербом, тризубом, в дитячому анімаційному фільмі російського виробництва «Ілля Муромець і Соловій-розбійник» (2007), - не згадуючи вже про апропріацію київських богатирів, як образів з українського історичного міфу, і багато інших випадків.

Інша методика, досить поширена зокрема у тоталітарних імперіях, - це фізичне знищення. Коли з якихось причин культурне надбання поневоленого народу не може бути перетравлено

\footnotetext{
${ }^{1}$ Саїд, Е. (2007). Культура і імперіалізм. Київ: Критика, 313

2 Забужко, О. (2005). Жінка-автор у колоніальній культурі, або знадоби до української гендерної міфології. EXLIBRIS <http://exlibris.org.ua/zabuzko/r05.html> (2020, жовтень, 01).

${ }^{3}$ Гундорова, Т. (2005). Післячорнобильська бібліотека. Украӥнський літературний постмодерн. Київ: Критика, 264.

4 Титар, О. В. (2015). Українські національні і культурні ідентичності у глобалізованому світі (на прикладі культури Слобожанщин : монографія. Харків: ХНУ імені В.Н. Каразіна, 349.

${ }^{5}$ Young, J. (2010). Cultural Appropriation and the Arts. John Wiley\&Sons, 168.
} 
імперією на власну користь, репресивний апарат може вибрати як модель поведінки саме такий варіант. Наприклад, практично стовідсоткове знищення матеріальних носіїв творчого доробку української інтелігенції періоду Розстріляного Відродження - фресок і барельєфів бойчукістів, кіновистав Леся Курбаса, накладів повістей та віршів М. Хвильового, М. Семенка, М. Зерова та багатьох інших, що пройшло практично непоміченим для світової спільноти, бо відбувалося за надійною інформаційною залізною завісою, яка убезпечувала безкарність подібних дій імперії щодо колонізованої культури.

Наступний метод засвоєння імперією культури колонії є надзвичайно цікавим, бо користується технологіями саме інформаційного суспільства, хоча і починав задовго до ери постіндустріального. Цей метод можна назвати методом перейменування, коли культурний продукт, який має джерело, походження, питомий грунт для розвитку і виникнення в іншій культурі, на підставі сторонніх його сутності, часто випадкових та/або формальних ознак переназивається як належний до іншої, а саме імперської культури. Прикладів дуже багато - тут і польський українець К. Малевич, який вперто іменується російським авангардистом, тут і гетьманський музика Д. Бортнянський, якого оголошують на світовій сцені російським композитором, і низка етнічних євреїв, яких, попри їх власну національну ідентифікацію, було записано у «рускіє». Одним із найзухваліших можна назвати проект спільного російсько-українського святкування 200-річного ювілею Т.Г. Шевченка, в якому його, за відгуками дослідників-очевидців, пропонувалося чествувати видатним російським художникомграфіком. Та доля склалася інакше, і у березні 2014 року про шевченківське перейменування як російського художника вже ніхто не згадував ${ }^{1}$. Одним із проявів цієї останньої стратегії перейменування, засвоєння імперською культурою продуктів колонізованого простору, $\epsilon$ і випадок 3 виданням у Російській Федерації роману Сергія Жадана видавництвом Амфора у 2005 році, в перекладі на російську, без зазначення, що це саме переклад ${ }^{2}-$ це був перший великий роман поета, можливо, видавці були певні, що його як прозаїка все одно ніхто не знає, і продати його як російського письменника буде легко і вигідно.

Крім попереднього, експропріаторів спадщини українського прозаїка могла окремо привабити репрезентація в романі логіки периферійності, так бажаної представникам імперського дискурсу стосовно осмислення життя колишньої колонії, та своєрідна туга за минулим, яку, попри власну позицію автора, можна відчитати в романах письменника в контексті реставрації імперського домінування. Однак, на нашу думку, ліричному герою Жадана йдеться не про ностальгійну тугу за імперією, радше про вдячність Минулому як такому. Виглядає так, що в нього немає іншого виходу, іншого опертя, бази для початку системи координат - Тамара Гундорова справедливо каже про бездомність і безбатьківство як об'єктивні ознаки жаданового топосу ${ }^{3}$. Для початку руху наративного вектору твору потрібна точка нуля, відлік. Саме таким нулем постає в романах Жадана минуле, яке в постколоніальній країні засадничо є спільним з імперським.

Дія роману «Ворошиловград» стартує під знаком Імперії в буквальному сенсі - на стіні його тимчасового дому, звідки починається і розкручується головна сюжетна лінія роману, висить мапа СРСР. «Я довго придивлявся, але не міг зрозуміти, у чому тут річ. Зрештою підчепив пальцем дембельський портрет Кочі й, потягнувши на себе, відірвав. Під фото знаходилась велика літера С. Це була карта. Скоріше за все, Радянського Союзу, і скоріше за все, географічна» ${ }^{4}$. Мапа не видна, якщо не приглядатись уважно, так само не надто видна імперія - але вона повсюдна. Дисперсована, деперсоналізована, дескурсивована (за М. Фуко) влада Імперії інклюзивно присутня скрізь, починаючи від Небесного Ворошиловграду, центрального образу роману, який відсилає нас не так до Граду вічного Старого Заповіту, як до мрії про золоту Загірну Комуну націонал-комуністів, будівничих раннього СРСР, закінчуючи дрібними деталями топоніміки та побуту (комсомол, що мав перевиховати Кочу, піонерія, для якої було побудовано табір відпочинку, комбриг Ворошилов,

\footnotetext{
1 Забужко, О. (2014). День поезії - Шевченко - чудеса. Facebook <https://www.facebook.com/oksana.zabuzhko/posts/10155112944713953> (2020, жовтень, 01).

${ }^{2}$ Улюра, Г. А. (2012). Сучасна українська проза в перекладах російською мовою: досвіди і практики.

Наукові записки НУ «Острозька академія». Серія Філогогічна, 27, 299-301

<http://nbuv.gov.ua/UJRN/Nznuoaf_2012_27_91>(2020, жовтень, 01).

${ }^{3}$ Гундорова, Т. (2005). Післячорнобильська бібліотека. Украӥнський літературний постмодерн. Київ: Критика, 160.

4 Жадан, С. (2010). Ворошиловград. Электронная онлайн библиотека

<http://booksonline.com.ua/view.php?book=173773> (2020, жовтень, 01).
} 
на честь якого було назване омріяне місто героя), що злилися 3 постколоніальним ландшафтом до ступеню повної нерозрізненості ${ }^{1}$. Споглядання трупу Імперії наводить на героя сон. У нульові роки Герман у колишній країні Рад не бачить нічого загрозливого, як і герой «Депеш Мод» в 1990-ті: «Я розумів, що цілком міг народитись в іншій країні, куди гіршій, наприклад з більш суворим кліматом чи авторитарною формою правління, де біля влади стояли б не просто ублюдки, як в моїй країні, а які-небудь поморочені ублюдки» ${ }^{2}$.

Певна позачасова небезпека, неявна загроза, яка відчувається на землях «Ворошиловграду» («запеклі танкові бої», про які весь час марить, всупереч реальному минулому часів Другої світової війни на тих теренах, бувший історик Ернст), ${ }^{3}$ оточує героя серед луганських степів. Сам статус того Ернста , яким наділяє його автор,- добровільний-захисник-аеропорту, впродовж чотирьох років 3 часу видання роману набуває принципово іншого значення. Ніби на підтвердження, що цей культурно-історичний простір, саме ця територія, мають свою, відмінну від загальної світової, логіку реальності, історія, яка зазвичай починається трагедією, а повторюється сатирою, тут вивертається рівно навспак: визначення доброволець, який захищає аеропорт, в романі Жадана постає сумною іронією, натомість в реальному житті, з кінця 2014 року, стає символом героїчного пафосу новітньої української історії, позначивши одну з реперних точок поточної, за своєю суттю, антиколоніальної, російсько-української війни.

Коли протагоніст рефлексує серед руїн індустріальної периферії імперії, що оточує героїв «Депеш Мод» у 1990-х, а героїв «Ворошиловграду» у нульових роках, йому нізвідки знати, що ця типова повсюдна, сливе всесвітня - а тому ніби безпечна - постмодерна загубленість у часі і просторі, відсутність ясних координат на цій території, у десяті обернеться реальною війною ${ }^{4}$. Чомусь саме на цій землі постмодерна невизначеність вибухне - можливо, саме через гранично (не)допустиму відсутність смислів? У формулюванні Жана Бодріяра, джерело зла є у байдужості та відсутності голосно артикульованих сенсів: «В своїй основі насильство, як і тероризм, не $\epsilon$ подія, а скоріш відсутність події, яка приймає форму вибуху, направленого всередину: вибухає політична порожнеча (а не злоба той чи іншої групи людей), мовчання історії (а не психологічний тиск на індивідуумів), байдужість та німотність. Таким чином, тероризм не $\epsilon$ якійсь ірраціональний епізод нашого суспільного життя: йому властива чітка логіка прискорення у пустці» ${ }^{5}$. Так, виявляється, зваблива лірична загубленість і невизначеність Небесного Ворошиловграду має межу - «ця остання межа особливо похмура / де надто неглибоко пекло і русла підземних руд / де час виступає ніби вугілля крізь грунт / де починається смерть і кінчається література» ${ }^{6}$.

Це прискорення зла в метафізичній пустці характеризує не тільки і не стільки поневіряння героя роману, а й постімперську пустелю сенсів, характерну для постколоніального стану. Лишається враження, що ця територія завершила лік часу, і нескінченна вдячність минулому постає заміною будь-якого майбутнього.

Ініціаційний шлях до дорослішання протагоніст наймолодшої генерації, яка представлена в творчості автора підлітками 1990-х в романі «Депеш мод», починає зі знаку закінчення - $з$ факту суб'єктивної історії, смерті вітчима одного з героїв, Саші Карбюратора. В той же час відбувається об'єктивна історія, смерть тоталітарної імперії, в якій народилися і до того часу проживали i автор, i всі його герої. Певною мірою ми можемо спостерігати відхід батьківських фігур в диспозиції ліричної романної дійсності: батьківщина, традиційна Велика Мати구, виявляється профанною матір'ю, псевдоматір'ю / мачухою-імперією, розвалюється і зникає, псевдо-батько/вітчим - виявляється профанним батьком, і з формальної, і з фактичної точки зору - він вкорочує собі віку, також зникає і здає позиції

\footnotetext{
${ }^{1}$ Костенко, Г. (2019). Ідентичність у пустці, або деякі риси стану постколоніальності у романі Сергія Жадана «Ворошиловград». Наукові записки НУ «Острозька академія». Серія «Культурологія», 20, 32-38.

2 Жадан, С. (2004). Депеш Мод. Ukrbooks.com <http://ukrbooks.com/ua/Depesh_Mod/> (2020, жовтень, 01).

3 Жадан, С. (2010). Ворошиловград. Booksonline.com.ua <http://booksonline.com.ua/view.php?book=173773> (2020, жовтень, 01).

${ }^{4}$ Костенко, Г. (2019). Ідентичність у пустці, або деякі риси стану постколоніальності у романі Сергія Жадана «Ворошиловград». Наукові записки НУ «Острозька академія». Серія «Культурологія», 20, 32-38.

${ }^{5}$ Baudrillard, J. (1993). The Transparency of Evil: Essays on Extreme Phenomena. London: Verso, 76.

6 Жадан, С. (2010). Кінець української силабо-тоніки: <http://www.knyga.in.ua/index.php/biblioteka/zh/ zhadan-serhii/1028-kinets-ukrainskoi-sylabo-toniky> (2020, жовтень, 01).

7 Забужко, О. (2005). Жінка-автор у колоніальній культурі, або знадоби до української гендерної міфології. EXLIBRIS <http://exlibris.org.ua/zabuzko/r05.html> (2020, жовтень, 01).
} 
відповідального Дорослого. Тамара Гундорова фіксує: «Так стверджується іманентність буття кочування, безбатьківщина, спільний стан усіх маргіналів» ${ }^{1}$. Джон Боулбі, британський психіатр та дослідник вікової психології, каже, що дитина, яка не отримала в певному віці досвід надійної, міцної підтримки з боку важливого для нього дорослого, назавжди залишається травмованою тою самотністю, і надалі ніби застигає в вічному дитинстві, іiі подальша доля визначається і зумовлюється постійним інфантильним станом ${ }^{2}$. Щось подібне відбувається і з героями романів - «ресентимент до минулого, недовіра до органічного колообігу життя, нелюбов до дорослішання, змужніння, старіння - такі ознаки посттоталітарного часу, які несе в собі бездомне покоління дев' яностих» ${ }^{3}$. Вони не знають, що таке зв'язок прихильності з відповідальним Дорослим, бо поруч з ними не було відповідальних дорослих. На відміну від сірих гусенят Конрада Лоренца, їм не показали навіть коробки, за якою можна слідувати, тому вони, як зграйка безпритульних сиріт, наслідують одне одного, і всі разом - директора сиротинця, в якості якого виступає черговий умовний лідер, який доста володіє навичками маніпуляції.

Відчуття тотального сирітства є невід'ємною характеристикою героїв романів Жадана. Попри виголошені в романах родинні зв'язки, вони більшою мірою діти не своїх батьків, а системи, бо і їхні батьки так само у свій час були позбавлені дорослості, піддані депривації відсутністю надійного дорослого поруч, а потім всиновлені патерналістською системою, що виховувала не самодостатніх Дорослих, а багато різновікових Дітей, інфантилізованих для кращого вжитку в якості керованих фігур. Приміром, важко назвати дорослим дядю Роберта, який в непростий ситуації сімейної трагедії, замість знайти племінника, що має бути присутнім на похоронах, посилає за ним трьох підлітків, «благословивши» їх рух та подорож декількома пляшками міцного алкоголю. Всі інші формально дорослі поруч з героями або чужі, або ворожі. Цю тугу самотньої, покинутої дитини, пустку на місці відповідального Дорослого, як і свою дитинну потребу в ньому, неодноразово озвучує протагоніст: «Чому мене ніхто не всиновив, скажімо, тоді, як я кілька діб жив на автовокзалі і спав на дерев'яних кріслах, або коли я кілька діб харчувався кип'ятком, зрештою, чому мене зараз ніхто не всиновлює, чому мене цей підар всиновити не може? я був би сином підарського полку, мені вже 19, я вже достатньо самостійний, я не потребую постійної уваги, мені не треба міняти підгузники і мене не потрібно годувати кашею... ...головне, щоби була батьківська увага, нормальна і постійна батьківська увага, справжня батьківська увага, як по телевізору» ${ }^{4}$

Рух героїв «Депеш Мод» від фальшивого батька, який загинув, до реального друга, що живе в піонерському таборі, як певному заповідному просторі інфантильності та підлеглості системі, послідовність зміни тоталітарної парадигми здитиненого існування новим самостійним дорослим життям не завершується перемогою, обривається - більша частина героїв не досягає цілі. А той один, хто знаходить реального Сашу, не наважується вирвати його з числа усуспільнених дітей, зруйнувати герметичність піонерського табору як інкубатору нових підлеглих, відкликати героя на місце поховання імперії з поля колоніальної залежності, щоби він зайняв місце покійного фальшивого Батька правдивим Сином. Тому, замість розкластися i бути похованою, Імперія загусає i муміфікується. Логіку життя не спинити, лихі дев'яності змінюються аморфними нульовими, рух продовжується, наступним після харківських підлітків його підхоплює шукач Небесного Ворошиловграду Герман, якому вже 33, і відкладати дорослішання нема куди, він також рухається і відшукує, блукаючи луганськими степами. Топос дороги є об'єктивно пов'язаним не тільки з рухом як таким, але і з певною територіальною приналежністю. Про органічний зв'язок «територія та культура» в контексті антиколоніальної боротьби згадує Е. Саїд: «Повільному і здебільше гостро суперечливому процесу відновлення географічної території, який становить осердя деколонізації (як свого часу - імперії), передує окреслення території культурної» ${ }^{5}$. Тобто володінню фактичному передує володіння апріорне, мисленнєве, емоційне та культурницьке. Подібний процес відбувається з Германом, перед тим, як стати де-факто (саме шлях від власності де-юре він і проходить) власником

\footnotetext{
${ }^{1}$ Гундорова, Т. (2005). Післячорнобильська бібліотека. Украӥнський літературний постмодерн. Київ: Критика, 170.

${ }^{2}$ Копець, Л. (2010). Класичні експерименти в психології. Київ: Видавничий дім «Києво-Могилянська академія», 283.

${ }^{3}$ Гундорова, Т. (2005). Післячорнобильська бібліотека. Український літературний постмодерн. Київ: Критика, 172.

4 Жадан, С. (2004). Депеш Мод. Ukrbooks.com <http://ukrbooks.com/ua/Depesh_Mod/> (2020, жовтень, 01).

${ }^{5}$ Саїд, Е. (2007). Культура і імперіалізм. Київ: Критика, 297.
} 
своєї частки української луганської землі, він емоційно вживається в цю приналежність. Герой Ворошиловграду все міряє і міряє ту територію, немовби відшукуючи своє коріння в ній, звикаючи до своєї єдності з цією землею - мандрує автобусом, їздить поїздом, перебігає пішки, сам, з табором, 3 випадковими попутниками. Мотив дороги в «Ворошиловграді»-це радше не про прийти кудись, це про кудись повернутися. Це намагання перевинайти себе як укоріненого в українську східну землю, нехай шляхом напівсліпих і не дуже усвідомлених виборів, намацування проблеми ідентичності та ідентифікації, які ще проявлять себе невдовзі досить голосно.

Можна сказати, що головний конфлікт романів - не суперечки з чужою владою чи з рейдерамиокупантами, а долання відчуження героїв від реальних обставин їх життя, їх входження в час і простір, у вік та територію. Їм важко, бо герої Жадана визначені і здепривовані власним тотальним сирітством. Якщо головні персонажі «Депеш Мод»- це дійсно фактично дуже молоді люди, яким ще не виповнилося 20, то Герман - це по суті ті ж самі підлітки, один з них, який певним дивом прожив ці 15 років, не зникнувши від пережитого в 1990-ті (не загинувши ані від передозу, ані під колесами авто у п'яному вигляді, ані від побиття в міліцейському відділку), і дожив-таки до тридцятитрьохрічного віку. Але дорослим так і не став. В «Депеш Мод» шлях до дорослості запускає смерть умовно батьківської фігури, у «Ворошиловграді» використовується той же прийом, хоча зникнення непряме - від'їжджає у безвість старший брат героя, залишивши його наодинці 3 дорослим життям і невизначеною територією у вигляді проблемного майна - автозаправки. Герман повертається з великого міста в луганські степи, до своєї землі і свого минулого, яке, як вже згадувалося, заколисує героя: «Я знайшов усіх своїх давніх знайомих, усі свої старі любові, усіх своїх вчителів та ворогів... Життя - штука жорстока, але справедлива. Хоча іноді просто жорстока» ${ }^{1}$ Жорстокість, ймовірно, полягає саме в необхідності дорослішання.

Окремо цікаве входження Германа в тісні стосунки 3 територією, його процес увласнення майна - на противагу вивласненню як процесу усуспільнення, якому підлягала ця земля попередні багато років імперського владарювання. Його опір, вперте небажання бути хазяїном можуть щиро здивувати, якщо не пам'ятати історію цієї території, а саме травми володіння землею: «Ліквідація класу вільних виробників, і знищення поваги в самому менталітеті нації до власності, і знищення звички i культури до самоорганізації - ці навики, які $\epsilon$ необхідними для повноцінного функціонування зрілої європейської нації, були ліквідовані», - характеризує наслідки історичних подій, зокрема Голодомору, на цих землях, письменниця і дослідниця О. Забужко².

Загалом проблему стосунків Германа з його власністю можна сприймати як своєрідну метафору колоніального відчуження імперією субалтерна від його ознак незалежності/самостійності та самодостатності / дорослості - від віку, майна, володіння тощо. «Брат, чогось остерігаючись, ще років п'ять тому завбачливо оформив усю документацію на мене. Стосунки у нас із ним були довірливими. Він знав, що навіть коли я захочу зробити із його бізнесом щось погане, то все одно не зумію, тому просто попросив не хвилюватись і підписатися в належних місцях. Надалі він навчився підробляти мій підпис» ${ }^{3}$. Тобто це майно, ця власність, ця територія належить Герману. Але, з огляду на те, що він не $є$ Дорослим, фактично управління лишається за Старшим братом, який просить молодшого просто підписати місцевий варіант будапештського меморандуму, і далі спокійно керує від його імені. Аж раптом щось стається, Старший брат відправляється чи то в Амстердам, чи то в Гаагу, і Герман лишається сам на сам із дорослішанням: «Найгірше, що брат нічого не сказав. І як тепер бути, я навіть не здогадувався Ще кілька днів тому я вважався вільним і незалежним експертом, котрий боровся незрозуміло з ким за демократію, а тепер ось на мені висіла нерухомість, з якою потрібно було щось робити, оскільки брата поруч не було і підробляти за мене підпис не було кому» ${ }^{4}$. Наявна криза ідентичності героя в момент отримання самостійності, дорослішання, майнової незалежності цілком відповідає типовим постколоніальним травмам і досвіду їх проживання.

Герман долає кризу стосунків із землею, процес увласнення завершується, приналежність до цієї території скріплюється кров’ю його близького друга, але логіка романної дійсності не залишає нам відчуття усвідомлення героєм його вибору - здається, дорослі дії ще не забезпечують дорослої, незалежної свідомості. Тому дещо вчуже звучить своєрідне мораліте роману, проповідь пастора

\footnotetext{
${ }^{1}$ Жадан, С. (2010). Ворошиловград <http://booksonline.com.ua/view.php?book=173773> (2020, жовтень, 01).

${ }^{2}$ Хвіст наслідків Голодомору тягтиметься ще не одне покоління - Оксана Забужко/ Дмитро Шурхало. Радіо Свобода. Політика <https://www.radiosvoboda.org/a/24779848.html> (2020, жовтень, 01).

3 Жадан, С. (2010). Ворошиловград <http://booksonline.com.ua/view.php?book=173773> (2020, жовтень, 01).

${ }^{4}$ Там само.
} 
протестантської общини, колишнього наркомана: «Як би там не було - життя робить із людей слабаків і зрадників, це я тобі як священик говорю...Я знаю, про що говорю. Справа не в церкві і не в наркотиках. Справа у відповідальності. Та вдячності. Якщо в тебе це $\epsilon-$ маєш шанс померти не останньою скотиною» ${ }^{1}$. Через втрати, кров, біль, смерть Герман доходить до простого мотто «вдячності та відповідальності», знов ж таки - до дитинної вдячності, але разом з тим, до дорослої відповідальності. «Все дуже просто: триматись один за одного, відбиватись від чужих, захищати свою територію, своїх жінок і свої будинки»².

Така проста до примітивності мораль звучить певним опертям в постколоніальній пустелі сенсів, характерній для романного простору Жадана. І отримує в подальшій позароманній дійсності несподівану актуальність, суголосну з історичним наративом даних територій, - а відтак знову повертається в площину вже нового, наступного роману автора, який, серед іншого, презентує читацькій спільноті саме ці, незвичні для постмодерного вокабуляра дії: відбиватись, захищати, триматись один одного.

Наступний роман Сергія Жадана сюжетно-просторовою фабулою нагадує попередні, автор продовжує оповідь про мандри протагоніста дорогами Східної України. Спостерігається певна біографічна лінія: умовний герой «Депеш Мод» виріс в невеликому містечку Луганщини чи Донбасу, поїхав у велике місто вчитися у виші, там зустрів розвал імперії, щодо подальшої долі за межами роману ми знаємо достеменно лише те, що, говорячи словами автора, «всі ці підлітки такі беззахисні проти років / і їхні серця тверді наче грифель / та разом з тим наче грифель крихкі / і тільки лишається слухати зиму / що звідкись та нависа / i пластиковою запальничкою прогрівать небеса», ${ }^{3}$ тобто фактично нічого. За сім років ми зате знайомимося з Германом з «Ворошиловграду», який виглядає на одного з таких підлітків, що закінчив виш, зробив кар'єру «незалежного експерта», щоб це не означало, але волею долі повертається з великого міста до рідної оселі десь в луганських степах. Паша, одіссей останнього роману, продовжує цю лінію - він виріс в невеличкому донбаському селищі біля залізничної станції, вивчився в великому місті, повернувся, і працює вже в рідних місцях, причому, шкільним вчителем - архетипічна посада в історії української культури, яка століттями колонізації та переслідувань кристалізувалася навколо саме таких осередків освіти. Однак, сам він на початку роману характеризує себе без жодного пафосу, іронічно-поблажливо - «який-не-який бюджетник». Та і представником української культури себе, вочевидь, не відчуває - як i представником чогось взагалі украӥнського. Крім хіба що мови, бо її він викладає, - втім, переходячи щораз в коридорі школи на російську.

Ми не можемо знати, чи ознайомлювався автор з літературно-критичними заувагами на адресу своєї творчості, але назва його наступного роману виглядає на підтвердження літературознавчим рефлексіям про бездомність та безбатьківство як координати його творчого всесвіту ${ }^{4}$. «Інтернат» підсумовує попередні 25 років поетичного та прозового доробку: так, ліричний герой Жадана насправді $є$ настільки загубленим, не укоріненим і осироченим, що це екстеріоризується наяв, заголовними літерами, певним маніфестом. Маніфестуючись, це сирітство відділяється від головного героя, і Паша виступає, мабуть, першим протагоністом, який має ознаки соціальної реалізованості, певної дорослості, відокремленості від дитинства - зокрема, його професія це підкреслює. Однак, відчуття непевності і загубленості, розмитості координат та ідентичності тепер вже дорослої людини, цілком відтворюються і в сьому романі. Цьому сприяють об'єктивні обставини життя донбаського залізничного селища, які знаходять своє відображення в романі: постімперська ідеологічна пустка, бодріярівське «мовчання історії» очікувано вибухає, і ця територія, а разом з нею і герої роману, знаходять себе посередині війни, біля рухливої лінії фронту. Джерело страху та небезпеки в попередніх романах не було оприявленим, існувало імпліцитно, натомість тут воно постає об'єктивною історичною даністю: «Страх - штука невидима, але всеохопна: ніби і не бачиш жодної загрози, довкола тихо, і навіть небо вгорі відблискує металевими пластинами, а ось саме лише усвідомлення, що ти на прицілі і що ... може будь-якої миті, незалежно від кольорів і рухів в небі, робить цю всю ситуацію незатишною» ${ }^{5}$

\footnotetext{
1 Там само.

2 Там само.

3 Жадан С. (2011). Ця молодість початку дев'яностих: 〈https://bit.ly/3mud67C> (2020, жовтень, 01).

${ }^{4}$ Гундорова, Т. (2005). Післячорнобильська бібліотека. Украӥнський літературний постмодерн. Київ:

Критика, 159.

5 Жадан С. (2017). Інтернат. Чернівці: Меридіан Черновіц, 53.
} 
3 настанням у світлі війни аксіологічної ясності закінчується ще один наскрізний емоційний сюжет творчості Жадана - вичерпується звична його героям ностальгійна туга за минулим як традиційним прихистком для дитинної свідомості, розсіюються ілюзії колишнього «золотого віку», «нормальної країни» 3 «нормальним дитинством». Цей сюжет закінчується якраз посередині романного дійства «Інтернату» як роману про антиколоніальну війну, та якраз усередині інтернату як установи для дітей, відчужених власними батьками. Речником колишньої імперії виступає педагог, фізрук інтернату: «Нам пощастило всім просто. У нас була нормальна країна, нормальне дитинство...У нас була справжня країна, нам не треба було боятися» ${ }^{2}$. Саме там, посередині інтернату, серед осирочених дітей, пролягає справжня лінія фронту роману, і з іншого боку несподівано подає свій голос жертва імперії: «3 дитинства я пам’ятаю лише відчуття голоду... Не всім (було непросто), далеко не всім. Мені от дійсно було непросто. Мені їсти було нічого. I мамі моїй також їсти було нічого. Хоча іï дитинство припало саме на той час, коли ви крали будматеріали (70-ті pp..XX ст. - Г.К.)... I не боялись ви не тому, що країна у вас така чудова була, а тому що вас завжди хтось прикривав: як не батьки, так райком комсомолу. А ось мене ніхто не прикривав. I їх показує вона рукою за спину, на фарбовані сині стіни,- теж ніхто не прикриє» ${ }^{3}$. Це промовляє керівничка закладу, Ніна, також педагог, тобто людина, що протиставлена дитинній свідомості. Між цими двома дорослими позиціями, посеред цього фронту ідей зависає головний герой, Паша: «Проти мене ніхто не воює. Я ні за кого...Я не знаю, хто стріляє» ${ }^{4}$. Він ретельно ховається від вибору та відповідальності: «Паша до такого не звик. Він навіть за свій клас не відповідав, звик списувати все на дитячу ініціативу та самостійність. I вдома ні за що не відповідав. Удома за все відповідала сестра» ${ }^{5}$. Та Ніна не залишає йому шансів: «Та знаєте, все ви знаєте. Кордон у нас на півдні. Державний кордон. Колишній державний кордон, - виправляє себе Ніна. - I стріляли саме звідти. І що тут не зрозумілого?...І якщо ви самі собі не хочете в цьому зізнатися, то хто вам винен?» ${ }^{6}$ У відповідь Паша замикається в байдужості та негативізмі, він йде до своєї маленької життєвої мети вивезти племінника, примовляючи: «Нікого не шкода, нікого».

Визначитись щодо своєї ідентичності в ситуації війни є об'єктивно небезпечним - ніколи не відомо, в чиєму оточенні та в який ситуації опинишся. Але не визначитись стає просто неможливим. Зрештою, подальша ситуація з фізруком і Ніною демонструє це однозначно: та сторона, яка воює за імперію, розорює інтернат, Ніна зникає, ії ідейний антагоніст фізрук важко поранений. Стає ясно, що бути ні за тих, ні за цих, не спасе - події просто йдуть своїм історичним плином, і вибір не гарантує ані смерті, ані спасіння від смерті.

Виглядає, що Паша до останнього опирається визначеності та ідентифікації свого боку війни, поки випадкова зустріч на закинутому вокзалі окупованого міста з божевільним старим не накидає іiі ззовні. Безпомильним оком юродивого, що приходить до героя нізвідки і зникає в нікуди, він визначає в Паші my сторону: «- Навалюють, - задоволено повторює старий. - Наші можуть. ... - А що ж ваші не відповідають? - раптом питає його старий. Паша здригається, дивиться на старого й розуміє, що ніякий він не божевільний, що все він чудово розуміє... I Пашу бачить просто наскрізь» 7 . Так сторонній погляд нарешті визначає Пашину ідентичність, міський божевільний бачить у ньому саме українську приналежність, якої доти не бачить сам Паша. Далі, коли на блок-пості він стикається зі своїм колишнім учнем, який не зміг досягти успіху в навчанні, зате зробив кар'єру у військах окупантів, і зверхньо пропускає Пашу на потрібний йому бік, Паша запізно згадує сього хлопця і вже не може опиратися власній визначеності, а значить, і власній відповідальності за те, що відбувається: «Як же так сталось? Як я не помітив, що мої учні тепер воюють проти мене? Як я це пропустив? Хоча, пробує він себе заспокоїти, чому проти мене? Не проти мене. До чого тут я? Та ладно, не проти тебе, тут-таки не погоджується він із собою, зрозуміло ж, що саме проти тебе, конкретно - проти тебе. Проти всього того, що з тобою пов'язане. ...І твій предмет, і твоя школа, і прапор, який над нею висить. Вони ж за це воюють. Точніше, проти цього.» ${ }^{8}$.

\footnotetext{
1 Там само.

2 Там само.

3 Там само, 157.

${ }^{4}$ Там само, 159.

5 Там само, 95.

6 Там само, 160.

${ }^{7}$ Там само, 232.

8 Там само, 254.
} 
Наприкінці роману протагоніст подвоюється - на відповідального Дорослого, якого до того десятки років і сторінок шукали герої Жадана, і на вдячну Дитину, яка нарешті має до кого, цілком за Дж. Боулбі, безпечно прив'язатися для справжнього дорослішання. На того, хто виведе 3 інтернату - і на того, хто з нього вийде.

Якщо рух у Депеш Мод - це рух кудись, певний напрямок, наприкінці якого треба знайти героя, рух у Ворошиловграді - це рух звідкись, шлях повернення героя до власної ідентичності через опір зовнішнім силам, то рух в Інтернаті - це дорога протагоніста кудись і звідти, яка поєднує попередній досвід і перевершує його. Це шлях Орфея, шлях туди і назад, в Пекло і до життя, за спасінням душі і на відміну від попередніх романів, майже без жодної іронії щодо високих формулювань мети і завдання героя. Паша виводить своє дитинне начало, племінника Сашу, з інтернату, повертає його на нормальне дитяче місце - в сім'ю, а себе на нормальне доросле місце - до рідного дому та звичної праці. Мертвотна патерналістська імперія, яка нескінченно множила ряди різновікових Дітей, застосовуючи для цього спеціальні інститути (інтернати), виглядає переможеною- здається, вдячність і відповідальність, коли перестали бути просто лозунгом нинішнього священикаколишнього наркомана, припинили іiі лік. Само по собі це перетворення було б неможливим - але герої Жадана, нарешті правильно розподіливши дорослість і дитинність, втіливши відповідно ці саме чесноти - дитинну вдячність і дорослу відповідальність, змогли подолати пустку імперії і вийти, як герої давнього міфу, з печери залежності на простір свободи.

Висновки. Зважаючи на вищесказане, убачаємо можливим виділити певні ознаки постколоніального, які можна зауважити в романах Сергія Жадана «Депеш Мод», «Ворошиловград» та «Інтернат».

1. В рамках романної дійсності ми можемо побачити реплікацію влади Імперії, яку відтворюють топоніміка, власні назви, згадувані реалії, які характеризують побутування героїв. Це є доцільним із художньої точки зору, оскільки додає романним подіям реалістичності, але водночас $є$ поновленням імперського владного дискурсу у свідомості читача.

2. Саме апеляція до спільної для імперії та колонії історичної пам'яті, поруч з заохоченням інфантилізації свідомості представників (пост)колоніальної спільноти є дієвим засобом гібридної війни імперії проти незалежності колишньої колонії. В художньому просторі романів ми можемо побачити, як імперське може певним чином узурпувати та паразитувати на особистих спогадах героїв про власне минуле.

3. Дієвим засобом постколоніального звільнення в текстах романів постає особиста відповідальність кожного члена постколоніальної національної спільноти, чітка ціннісна ієрархія в суспільстві, яка високо ставить цінність державності та національної окремішності для колишньої колонії, в той час як відмова від такої відповідальності, хаотизація та розмитість сенсів в рамках романної дійсності породжує певну пустку, яка небезпечна деструктивними соціальними явищами, а саме підготовкою плідного грунту для військової агресії з боку колишньої імперії.

\section{References:}

1. Hundorova, T. (2005). Pisliachornobylska biblioteka. Ukrainskyi literaturnyi postmodern [Post-Chernobyl Library. Ukrainian literary postmodern]. Kyiv: Krytyka. [in Ukrainian].

2. Zhadan, S. (2010). Voroshylovhrad [Voroshilovgrad]. Elektronnaya onlayn biblioteka [Electronic online library] $<\mathrm{http}: / /$ booksonline.com.ua/view.php?book=173773>. (2020, October, 01). [in Ukrainian].

3. Zhadan, S. (2004). Depesh Mod [Depeche Mode]. Ukrbooks.com <http://ukrbooks.com/ua/Depesh_Mod/> (2020, October, 01). [in Ukrainian].

4. Zhadan, S. (2017). Internat [Boarding school]. Chernivtsi: Merydian Chernovits. 336. [in Ukrainian].

5. Zhadan, S. Kinets ukrainskoi sylabo-toniky [The end of Ukrainian syllabic tonic]: <http://www.knyga.in.ua/index.php/biblioteka/zh/zhadan-serhii/1028-kinets-ukrainskoi-sylabo-toniky> (2020, October, 01). [in Ukrainian].

6. Zhadan, S. (2011). Tsia molodist pochatku devianostykh [This youth of the early nineties]. Ukrayinskyy Tsentr [Ukrainian Center] <https://bit.ly/3mud67C> (2020, October, 01). [in Ukrainian].

7. Zabuzhko, O. (2014). Den poezii - Shevchenko - chudesa [Poetry Day - Shevchenko - miracles]. Facebook <https://www.facebook.com/oksana.zabuzhko/posts/10155112944713953> (2020, October, 01). [in Ukrainian].

8. Zabuzhko, O. (2005). Zhinka-avtor u kolonialnii kulturi, abo znadoby do ukrainskoi gendernoi mifolohii [Woman-author in colonial culture, or needs for Ukrainian gender mythology]. 〈http://exlibris.org.ua/zabuzko/r05.html> (2020, October, 01). [in Ukrainian].

9. Kopets, L. (2010). Klasychni eksperymenty v psykholohii [Classical experiments in psychology]. Kyiv: Vydavnychyi dim Kyievo-Mohylianska akademiia. [in Ukrainian]. 
10. Kostenko, H. (2019). Identychnist u pusttsi, abo deiaki rysy stanu postkolonialnosti u romani Serhiia Zhadana «Voroshylovhrad» [Identity in the wasteland, or some features of the state of postcolonialism in Sergei Zhadan's novel «Voroshilovgrad»]. Naukovi zapysky NU «Ostrozka akademiia». Seriia «Kulturolohiia» [Scientific notes of Ostroh Academy National University. Series «Culturology»], 20, 32-38. [in Ukrainian].

11. Said, E. (2007). Kultura i imperializm [Culture and imperialism]. Kyiv: Krytyka. [in Ukrainian].

12. Tytar, O. V. (2015). Ukrainski natsionalni i kulturni identychnosti u hlobalizovanomu sviti (na prykladi kultury Slobozhanshchyny) [Ukrainian national and cultural identities in the globalized world (on the example of Slobozhanshchyna culture): monograph]. Kharkiv: KhNU imeni V.N. Karazina. [in Ukrainian].

13. Uliura, H. A. (2012). Suchasna ukrainska proza v perekladakh rosiiskoiu movoiu: dosvidy i praktyky [Modern Ukrainian prose translated into Russian: experiences and practices]. Naukovi zapysky NU «Ostrozka akademiia». Seriia Filohohichna [Scientific notes of Ostroh Academy National University. Philological series], 27, $299-301$. <http://nbuv.gov.ua/UJRN/Nznuoaf_2012_27_91>(2020, October, 01). [in Ukrainian].

14. Radio Svoboda. Polityka (2012) [Radio Svoboda. Policy (2012)]. Khvist naslidkiv Holodomoru tiahtymetsia shche ne odne pokolinnia - Oksana Zabuzhko/ Dmytro Shurkhalo [The tail of the consequences of the Holodomor will last for more than one generation - Oksana Zabuzhko / Dmytro Shurkhalo].

<https://www.radiosvoboda.org/a/24779848.html> (2020, October, 01). [in Ukrainian].

16. Baudrillard, J. (1993). The Transparency of Evil: Essays on Extreme Phenomena. London: Verso. [in English].

17. Young, J. (2010). Cultural Appropriation and the Arts. John Wiley \& Sons. [in English]. 